This item was submitted to Loughborough's Research Repository by the author.

Items in Figshare are protected by copyright, with all rights reserved, unless otherwise indicated.

\title{
The academic game: Compliance and resistance in universities
}

\section{PLEASE CITE THE PUBLISHED VERSION}

https://doi.org/10.1177/0950017017695043

\section{PUBLISHER}

SAGE $\odot$ The Authors

\section{VERSION}

AM (Accepted Manuscript)

\section{PUBLISHER STATEMENT}

This work is made available according to the conditions of the Creative Commons Attribution-NonCommercialNoDerivatives 4.0 International (CC BY-NC-ND 4.0) licence. Full details of this licence are available at: https://creativecommons.org/licenses/by-nc-nd/4.0/

\section{LICENCE}

CC BY-NC-ND 4.0

\section{REPOSITORY RECORD}

Kalfa, Senia, Adrian Wilkinson, and Paul J. Gollan. 2019. "The Academic Game: Compliance and Resistance in Universities". figshare. https://hdl.handle.net/2134/32749. 


\title{
The academic game: compliance and resistance in universities
}

\section{Senia Kalfa*}

Department of Marketing \& Management, Faculty of Business \& Economics, Macquarie University, Sydney Australia

\section{Adrian Wilkinson}

Centre for Work, Organisation and Wellbeing, Griffith University, Australia

\section{Paul J. Gollan}

Faculty of Business, University of Wollongong, Australia

\begin{abstract}
This article draws on the sociology of Bourdieu to explore how academics respond to managerialist imperatives. Bourdieu's metaphor of the game is applied to a case study of a regional Australian university, which underwent significant changes in 2007, the most notable being the introduction of performance appraisals. In-depth interviews ( $\mathrm{N}=20)$ reveal evidence of symbolic violence: staff compliance with and complicity in the changes. This is evident in the way that the interviewees, mostly early career academics, chose to play the game by concentrating their efforts on increasing their capital within the new order. To further support this argument, signs of resistance to the new regime were explored. Findings show that vocal resistance was sparse with silence, neglect and exit being the more realistic options. The article concludes that it is academics' illusio, their unwavering commitment to the game, which neutralises resistance by pitting colleagues against each other.
\end{abstract}

Keywords: academia, Bourdieu, game, illusio, performance appraisal, resistance, symbolic violence

\section{* Corresponding Author:}

Senia Kalfa, Department of Marketing \& Management, Faculty of Business \& Economics, Level 4, E4A Building, Eastern Road, Macquarie University, NSW 2109, Australia E: senia.kalfa@mq.edu.au 


\section{Introduction}

Literature on the changing nature of academic work documents the encroachment of managerialism in the Higher Education (HE) sector, an approach which has become the guiding principle for public service modernisation. Allen Collinson (2000:159) argues that diminished government funding has compelled Higher Education Institutions (HEIs) to 'become more entrepreneurial' so as attract income from other sources, thus promoting market-orientation, an argument shared by Czarniawska and Genell (2002). HEIs are now considered to be providers of 'value adding, commercially orientated services' to stakeholders, a shift which 'implies the gradual displacement of traditional ideals of professionalism or at a minimum their contamination with the alternative logics of entrepreneurship and managerialism' (Faulconbridge and Muzio, 2008:8).

Managerialism has seen the use of more 'muscular management styles' (Anderson, 2008:251) implemented through a range of practices, such as performance appraisals (PAs). Overwhelmingly, scholars argue that PAs are ill-suited to the nature of academic work because academics traditionally 'do much of their work alone, delivering their own courses and pursuing their own research’ (Baldry and Barnes 2012: 230). In a seminal article, Townley (1997) examines the introduction of PAs in British institutions arguing that universities at the time resisted government pressures for the introduction of judgemental performance appraisals and used developmental ones instead. Similarly, in assessing the implementation of PAs in The Netherlands, Sousa, de Nijs and Hendriks (2010) argue that academics' power to resist adverse implications stemming from performance management has been underestimated. More recently though, Kallio, Kallio, Tienari, and Hyvonen (2016: 702) examine the introduction of performance management practices in three Finnish universities and find that 'it gives rise to a new academia', one where measurement and metrics encourage competition between academics. This competitive ethos has been found to be pernicious for collegiality (Archer, 2008). 
Overall, research examining the impact of such managerialist practices in academia documents academics' ideological opposition towards such trends. At the same time, scholars are almost unanimous in their conclusion that academics have largely complied with managerialist imperatives and document ways in which they cope with them. While existing research has generated important insights, there is a lack of understanding of the reasons behind academics' acquiescence as well as behind any resistance they proffer. This research gap results from inadequacies in the conceptualisation of academic work, which this article overcomes by adopting Bourdieu's metaphor of the 'game'. Through said metaphor, this study illustrates that academics' motivation to resist (or not) depends on how much they are invested in the game.

To do so, this article presents a qualitative case study of an Australian university, which adopted a formal performance appraisal process for the first time. Drawing on Bourdieu's concepts of field, doxa, capital and illusio, the core question this study explores is whether academics in the case organisation complied with these changes or resisted and why. Through thematic analysis, evidence of symbolic violence is found in the form of staff compliance with the changes. This claim is supported in showing that interviewees chose to pursue career advancement by playing the game and concentrating their efforts on increasing their capital within the new order, while misrecognising the intent to enforce and sustain managerialist practices. To further support this argument, resistance to the new regime was explored through an examination of how staff at the case study organisation used the elaborate participative structures available in the academy. The article finds that vocal resistance was sparse with silence, neglect and exit being the more realistic options. As much as it is imposed by 'hierarchy and agenda setting' (Alvesson and Spicer, 2016: 42), this study concludes that academics ‘take the game seriously’ (Bourdieu, 1998: 76) and by doing so they legitimise it. 
The article begins with a literature review on resistance to managerialism in the academy and continues by introducing the conceptual framework and providing a detailed account of the methodology. On this basis, the introduction of PA at the case study organisation is outlined and the ways in which staff complied to the new rules of the game are explored. This material is supplemented with examples of resistance that mostly sought to neutralise the effect of managerialism. A discussion section follows presenting how the insights generated by the study contribute to the understanding of academic work and a conclusion is provided regarding the practical implications of the article’s findings.

\section{Resistance and compliance in the academy}

Davies and Petersen (2005: 34) ask: 'how is it, given that neoliberal discourse can so easily be constituted as monstrous and absurd, that academics appear to have engaged in relatively little systematic or widespread resistance and critique of it'? Overwhelmingly, research documents academics’ strong ideological objections to managerialism coupled with a reluctant compliance to ‘the professional bureaucracy which severely curtails their autonomy’ (Alvesson and Spicer 2016: 30). For example, in examining how younger British academics (under the age of 30) construct their identities, Archer (2008) highlights five discourses that allow them to negotiate the pressures of HE, four of which focus on self-protection. Teelken (2012) through 48 interviews in 10 universities in The Netherlands, the UK and Sweden finds that for the most part academics either respond to requirements at a superficial level, an approach she calls symbolic compliance (see also Hughes, 2005), or decide to play by the new rules out of professional pragmatism. Similarly, Clarke, Knights and Jarvis (2012) interviewed British business school academics and find that although most felt a sense of disappointment with academia, only a minority are actively resisting. Most of the 48 interviewees either used the research interviews to express their disquiet, or escaped through cynicism and disengagement or even altered their own identities 'if there were expectations of reward' (Clarke et al., 2012: 10). Similar conclusions are reached by Leathwood 
and Read (2013) who through 71 email interviews with British academics find that contestation happens only on an ideological level with compliance being the only option. Finally, Ylijoki and Ursin (2013) explore how Finnish academics make sense of the changes in HE and find narratives of mostly ideological resistance within their 42 interviews.

On the other hand, Clegg (2008: 340) maintains that academics do resist managerialism, albeit passively and individually, by carving out spaces, such as creative projects which allow them to 'practise with integrity'. Similarly, Anderson (2008) in a qualitative study of Australian academics, finds that resistance takes many forms with every day and covert strategies, such as avoidance or forgetting, being preferred to open, public acts. By drawing on James C. Scott's notions of 'weapons of the weak' and 'hidden transcript', she argues that academics' resistance is a force to be reckoned with as academics 'are skilled in rebellion and innovation' (Anderson, 2008: 267). However, in an earlier article, Anderson (2006:588) calls academics to 'consider more deeply the ways in which the forms of resistance they employ ultimately affect their own wellbeing', since her interviews pointed to academics sacrificing their own leisure time to do 'real work - research' as opposed to all the administrative duties that neoliberal cultures have imposed.

\section{Conceptualising resistance in the academy}

While existing research is critical in documenting academics' dissatisfaction with the changes in HE, it has not sufficiently explained why academics are complying to managerialist imperatives or when they do resist, they do so on an individual level. The article therefore draws on Bourdieu's relational method of social inquiry and his metaphor of 'the game' which are particularly suitable for a nuanced examination of how academics respond and adapt to the introduction of managerialist imperatives, such as PAs. In this study, academia is conceived of as a field in the Bourdieusian sense, a social space where everyone wants to secure the 
most advantageous position (Grenfell, 2008). As with any other field, academia has dynamic boundaries (Bourdieu and Wacquant, 1992) and a 'doxa', a set of fundamental principles and rules of behaviour which agents in a field view as inherently true (Webb, Schirato and Danaher, 2002), internalise and reproduce.

Due to its relational nature, Bourdieu and Wacquant (1992) compare the concept of the field to a 'game', in which all agents have a stake as well as an investment. Players in the game are engaged in a competition aimed at improving or maintaining their position in the field by increasing or maintaining the levels of capital they possess or by changing the rules of the game (Bourdieu and Wacquant, 1992). Hence, a field is characterised by tensions and contradictions which give rise to conflict (Bourdieu, 2005), especially when the social agents acting within a field attempt to redefine what is to be considered as power (i.e., capital) and how power is to be distributed (Webb et al., 2002). In these struggles, most social activity is played out according to individuals' interests and their investment in the game (illusio). Illusio 'denotes how we are caught up in the game, our belief that it is worth playing, our commitment to it, and our investment in its stakes’ (Colley, 2012: 324).

This framework also incorporates Bourdieu's concept of misrecognition: the fact that agents tend to 'forget' that they are caught up in the game. Misrecognition is important because 'it underscores that the exercise of power rests on a foundation of a shared belief and presupposes a kind of active complicity on the part of those subjected to it' (Bourdieu, 1991: 23). Misrecognition is the key to what Bourdieu and Wacquant (1992: 142-143) call symbolic violence which they define as 'the violence which is exercised upon a social agent with his or her complicity’. As such, symbolic violence invokes mechanisms of social control which are not always explicit (Kamoche, Kannan, and Siebers, 2014). In short, viewing academia as a field permits the identification of the ways in which academics respond to initiatives that are 
introduced to satisfy financial, economic and policy pressures exerted on universities under the rational, neo-liberal agenda.

\section{Methodology}

\section{Design and data collection}

The findings are based on a single, qualitative case study. Specifically, this article draws on a critical case as defined by Flyvbjerg (2006: 230): 'a case whose purpose is to achieve information that permits logical deductions of the type: if this is (not) valid for this case, then it applies to all (no) cases'. In other words, the case study is used to provide insight into an issue, while the case itself is of secondary interest. Stake (1995) suggests that case studies should not be chosen if the purpose is to generalise to a population, as traditional studies do this better. Instead, Yin (2003) pointed out that case studies should be used for analytical generalisation, that is to expand and generalise theories. As analogous changes are being implemented in other universities, this case study organisation is a good example for the study of academics’ responses to managerialism.

The analysis is based on 20 in-depth semi-structured interviews conducted in August 2012 in a regional Australian public university (hereon, The University). Participant recruitment occurred via an email which was circulated to all staff and which allowed participants to respond directly to the researchers to not jeopardise confidentiality. The pool of interviewees is comprised of 10 academics, most of whom were Early Career Academics (ECAs), and 10 professional staff. Table 1 below provides some brief information regarding the participants as well as the pseudonyms used throughout the article. Though we acknowledge the rather small sample, and understand that one can never be sure that gathering new data will not lead to new insights, sufficient data were assumed when theoretical saturation was reached and nothing new was being added by additional interviews. 


\section{- $\quad$ INSERT TABLE 1 HERE -}

To assess the validity of the findings, Hammersley’s (1990: 61) criteria of plausibility and credibility are applied. Plausibility judges a claim as 'very likely to be true given our existing knowledge' and credibility asks whether the researcher's 'judgement on matters would be accurate given the nature of the phenomena concerned, the circumstances of the research and the characteristics of the researcher'. Reviewers are to estimate 'both the likelihood of an error given the nature of the phenomenon and the chances of error because of the character of the researcher's or informant's access to it and/or because of bias' (Hammersley, 1990: 74).

It is necessary to acknowledge that one could consider this insider research, in the sense that we have intrinsic knowledge of academic work in Australia, being academics ourselves. Insider research has often been perceived as problematic due to the researchers' emotional investment in the setting thus jeopardising intellectual rigour (Brannick and Coghan, 2007). Throughout data collection and analysis, the potential for bias was acknowledged and steps to overcome undue influence were taken. For example, most interviews were conducted by two researchers to ensure nothing was taken for granted, the obvious questions were asked, assumptions were challenged, and sensitive topics were raised (Mercer, 2007). Further, the authors refrained from expressing personal opinions about performance appraisals in academia to the interviewees. Finally, reflective notes were kept throughout data analysis and frequent discussions were held between the authors to minimise undue influence.

Finally, Hammersley (1990: 64) maintains that research findings must 'not only be valid but also relevant to issues of public concern'. This topic addresses both sub-criteria for relevance, in the sense that it relates to an issue of public importance and its findings contribute to existing knowledge. 
The interview schedule was semi-structured and the interviews were undertaken as guided conversations. Interview duration ranged between an hour and an hour and a half. In accordance with interviewing practice, all interviews were tape-recorded and transcribed verbatim. In insider research, one ethical dilemma researchers face is what to tell colleagues before and after they participate in the study. In this study, full disclosure was practised and prior to recording, the interview themes were presented to the participants: the introduction of the performance appraisal scheme; whether employees were consulted when it was initiated; their 'lived' experiences of the performance appraisal; how they cope with the workload; their overall evaluation of the changes at The University. All interviewees seemed to be at comfort discussing the above with only two asking the interviewers to reiterate a guarantee for anonymity which was already stated in the consent form.

\section{Data analysis}

Interview data have been subjected to a thematic coding procedure following principles of The Framework (Ritchie and Spencer, 2011) using NVIVO 10. This coding process began with familiarisation through immersion in the interview transcripts. The next step was constructing the thematic framework upon which to examine the data. This drew on 'a priori issues, informed by research and introduced into the interviews via the topic guide; emergent issues raised by the respondents themselves and analytical themes arising from the recurrence or patterning of particular views or experiences' (Ritchie and Spencer, 2011: 313). The third step was systematic application of the identified themes to the transcripts followed by charting summaries of each theme. The final stage is mapping and interpretation where 'the analyst begins to pull together key characteristics of the data, and to map and interpret the data set as a whole' (Ritchie and Spencer, 2011: 320). Having identified the general patterns of resistance and compliance in the case study organisation, the analysis then focused on 
examining those through a Bourdieusian lens to shed more light into the reasons behind forms of resistance or acquiescence.

\section{Playing the game: compliance and resistance co-exist}

The findings will be presented in three inter-related areas. First, the changes that occurred at The University will be presented as context. Based on this information, the metaphor of the game will be used to demonstrate how academics simultaneously complied and resisted the new PA requirements.

\section{Changing the rules of the game: the introduction of PA}

The period of change begins in 2007 with the appointment of a new Vice-Chancellor (VC), whose appointment is associated with a 'burning deck' scenario. The interviewees articulated the past of The University 'as a problem, as something that needs to be escaped from' (for a different university but similar construction of a crisis see Parker, 2014: 287). The crisis was attributed to financial predicaments caused by diminishing student enrolments (Persephone, Professional), duplication of services (Socrates, Professor), poor performance with grants and research output (Iphigeneia, Associate Professor, Head of Department) and a weak brand. According to Socrates (Professor), this chronic underperformance put jobs at The University at stake.

In line with managerialist principles for cost efficiency, the appointment of the new VC was accompanied by a series of reforms, beginning in 2008, which saw the centralisation of professional departments and the outsourcing of back office processes. Following these administrative reforms, The University embarked on a second round of changes in 2009, beginning with the updating of the Academic Promotions policy, collapsing levels B (Lecturer) and C (Senior Lecturer) 'to create an assistant professor designation. Newly 
appointed assistant professors are on arrangements for up to seven years, but they only become continuing ${ }^{\mathrm{i}}$ if they are successfully promoted to Level D [associate professor]' (Socrates, Professor). Second, an annual PA was introduced that evaluated staff performance in three areas: teaching and learning; research and research training and; community engagement and service. In each of the performance areas staff could be rated as satisfactory, significant, or outstanding with each one of these scales being broken down into specific deliverables ${ }^{\mathrm{ii}}$. Socrates (Professor) explained that 'part of the ethic is to reward performance, to attract people who want to go to the top... It's gobbledygook really, but satisfactory is unsatisfactory (italics our own). Someone merely being satisfactory is not good enough'.

One of the requirements of the newly instated PA process was that staff members had to hold a $\mathrm{PhD}$ and focus on research, both of which represented a significant change in the rules of the game. As a former teaching institution, the academic population of The University was primarily comprised by individuals from non-research backgrounds. Thus, the introduction of the PA was accompanied with Voluntary Separation and Early Retirement Schemes, which 106 permanent members of staff took (HR department). This is a significant number considering that the entire community was comprised of approximately 400 full-time academics. Many of the staff that chose to leave were nearing retirement age (Penelope and Roxanne, both Assistant Professors; Alkmini, professional). However, it could also be argued that staff's choice to exit the organisation reflects either their relative lack of power in The (new) University or their limited aspirations to progress their careers within the changing field. To replenish this exodus, The University engaged in a recruitment drive for ECAs (Nepheli, professional). As such, this case study shows the dividing lines between active players in the game and those choosing to not participate in it. The former are the ones who accepted the new game and either comply or resist (discussed below) and the latter the ones that chose to exit the field. 


\section{Compliance and complicity}

Overwhelmingly, interviewees 'recognise[d] the game and its stakes' (Bourdieu, 1998: 77) and focussed on growing their capital by increasing their research output, applying for grants and attaining high teaching scores. In doing so, academic staff at The University could protect themselves on an individual level and secure their future employment as management expectations to achieve highly on all three areas were made very clear: '[the PA] forces [staff] to focus on things that they need to be doing. It sends a really clear message that this is what we value, this is how you should be spending your time' (Iphigeneia, Associate Professor, Head of Department).

With regards to external funding and research output, the interviews highlighted that succeeding in one increased the chances of succeeding in the other. Grants allowed their holders to take time off teaching and focus on writing articles, which would in turn increase their chances of promotion to Level D and of attaining a continuing contract. The University was providing workshops on grant writing, but the participants knew that the rules of the game almost dictate the need for 'someone senior [to] put their name on the grant' (Penelope, Assistant Professor) to increase the chances of funding. Interviewees who had not cultivated these relationships with senior academics were worried about potential ramifications for their job: 'I was refused by three senior staff as being too busy to be able to mentor me. I found this quite difficult' (Daphne, Assistant Professor).

Interviewees were particularly dissatisfied with the inclusion of teaching scores as a measure of success, because it represented 'oversimplification... it discourages innovation, encourages you to maybe make things easier for your students' (Leto, Professional). Even if interviewees were cognisant that satisfaction scores 'are a bad measure of teaching' (Roxanne, Assistant Professor), it did not mitigate their attempts to attain them: 'I strive to 
get my satisfaction scores as high as I can. Sometimes whatever you do there's still some students (sic) who are not happy. If you teach a hard subject you get even worse results' (Phillip, Professor).

The competitive nature of working at The University was further highlighted by Phillip (Professor) who explained that staff even had to compete against each other to sit in committees:

Because we are a small university, the opportunities are quite limited. You can't have the whole university full of professors or full of deans. For example, one criterion for promotion is service and activity for the university... be member of committees or chair of this and that. The number of committees is so small. Membership is so competitive, so difficult to get in. That will limit the number of opportunities to shine.

Removing such type of tasks from one's portfolio could significantly disadvantage that individual, a point made by Daphne (Assistant Professor) whose role as Post Graduate coordinator was given to someone else.

Participating in this new game led to high levels of stress and in some cases, burnout. Roxanne (Assistant Professor) pointed to the long hours staff felt obliged to work to meet their targets, while Medeia (Assistant Professor) playfully asked 'what else do you do on weekends' when questioned about how she coped with the requirements of her role. Chloe, an Assistant Professor who was given an Associate Dean role for six months in addition to teaching a large undergraduate unit, suffered from burnout, a problem that Elektra (Professor, Head of Department) also mentioned as an issue she was trying to resolve in her department.

It could be argued that the predominance of recently joined ECAs made them more vulnerable because they 'are engaged in the process of becoming academics' (Archer, 2008: 272) within the context of neoliberalism and its associated competitiveness and high 
performance expectations. Having never experienced anything else, it is understandable that staff accepted the game and played by its rules. Additionally, the instability of the labour market was highlighted as a critical factor for staff compliance with the new rules of the game. Medeia (Assistant Professor) explained:

I was a tutor for two years in [name of previous employer] and then I was an associate lecturer while I did my PhD. I rolled from one contract to another every six months or every year. There's no opportunity to get superannuation or long service leave or any of the good stuff you work for. So from my perspective, a seven-year contract is quite substantial.

This attitude was of benefit to management:

[The academics] that are here have accepted [the changes] because they can see that they are to their benefit and to the benefit of the university. We've got a new set of young, early career researchers, who are very eager and keen. They have taken the happy pill and joined us because they see that we had a trajectory and we had a plan that we wanted to work through. They are the non-objectors (Phillip, Professor).

\section{Resistance as voice or exit}

Bourdieu (1977: 188) argued that 'the most successful ideological effects are those which have no need of words, and ask no more than complicitous silence'. As such, to strengthen the argument of symbolic violence and to fully appreciate how the game is being played, resistance was explored, such as speaking up against the new regime. First, examples of overt resistance were identified by paying attention to the extent to which the interviewees used the array of participative structures readily available in the academy to voice their concerns. Thus, long-serving staff members of The University were asked about the extent to which academics challenged the new focus on research and the performance expectations. Phillip 
(Professor), a member of the academic board, recalled: 'some of the ideological objections were that "why should I be reviewed, I'm a professor, I know what my field is, who are you to tell me what to do in my field”'. Socrates (Professor), also a member of the top leadership of The University, maintained that staff were concerned 'about the quality of the supervisor' that would conduct the PA, a point also made Thalia (HR manager). Nepheli (HR professional) who was integral in the development of the PA as a system argued to that end: '[the PA] was culturally difficult, because you're not challenging an abstract concept, you're challenging that person's belief in themselves and what they're passionate about. How do you tell someone that their discipline is not worthy of pursuit?'

Additionally, interviewees were asked whether they formally voiced their concerns about the PA process and its associated expectations, to their supervisors, to HR or other faculty or university-level forums. To that end, Roxanne’s (Assistant Professor) response captured the shared sentiment:

I've raised it at a promotion seminar and other university things related to the PA and they said this isn't the place. But I don't know where the place is... so the message is loud and clear. Be quiet about the PA.

The interviewees also had the opportunity to speak out at the Vice-Chancellor's forums which were scheduled every six weeks. Although the interviewees saw these as an opportunity to get a progress update, Leto (Professional) highlighted that in those forums staff ‘prefer to listen’ and Elektra (Professor, Head of Department) claimed that while some staff might raise questions during the forums 'no one really challenges [the VC]. I think people might be a bit too scared'.

Moreover, the extent to which interviewees used the National Tertiary Education Union (NTEU) to voice their discontent about the performance expectations was explored. The 
following quote by Leto (professional) captured what interviewees thought of its actions: 'it doesn't seem to have been terribly relevant. The VC might make an announcement and then the union will send around an email saying this is a lousy idea but it doesn’t really seem to get through to people’. Similar responses were given by Roxanne, Iphigeneia and Penelope (academics) as well as Helen and Alkmini (professionals). In fact, the only structure found where individuals could raise issues of concern, were the lunches the VC held with newly arrived academic staff. Some of the interviewees who were invited to such an event, had found that experience rewarding: 'that was probably the first time I've felt we've really had a voice’ (Chloe, Assistant Professor).

Furthermore, one example of what could be classified as misbehaviour was identified, in the form of gaming the PA. For example, Roxanne (Assistant Professor) explained that for her performance to be evaluated as significant or outstanding, she would 'never put anything that [I] haven't already got almost in the bag'. This was an argument shared by Elektra (Professor, Head of Department) who realised that she would have to 'be a bit more careful when I write this next year' reflecting on the pressure to achieve every single one of her set objectives. Alkmini, a professional staff member who had a $\mathrm{PhD}$ and was employed at The University in a teaching-only capacity, claimed that in her department the supervisor arranged a 'pre-PA meeting to agree on what will happen in the official PA meeting. I think it's more coaching you to say the right things within the PA meeting'.

Only limited examples of academics openly challenging management were identified, mostly relating to perceived unfairness in the $\mathrm{PA}$, so in effect challenging not the principle but the operation of the system. For example, Hermione (Assistant Professor) recalled when she was downgraded in the community engagement criterion: 
I was just outraged! I'm usually a doormat and just take it but I thought, no, because I'm going for a promotion. So, I wrote back and said "I want your justification why you downgraded me to satisfactory”. When they didn't answer, I copied in HR and then they came back and said “okay, okay you’ve got outstanding”.

A similar example was given by Penelope (Assistant Professor) who received low student satisfaction scores and was thus rated as an unsatisfactory teacher in her PA. When she challenged that the score measured the course content not her teaching ability 'there was a bit of an argument, but about two weeks later they came back and said okay, well you can have satisfactory’. In a related matter, Penelope (Assistant Professor) challenged her supervisor by raising objections about the workload model and unfair distribution of large teaching units but was told 'that's the way The University does it'. Chloe and Hermione (both assistant professors) who faced similar workload issues in their department, were vehement critics of the solution provided by their Faculty: 'their response was to run mindfulness courses and workshops on efficiency. Quite frankly, that's just disrespectful when you've got such a large proportion of the faculty saying they're drowning in the workload'.

It would seem therefore, that the work environment at The University was not conducive to overt forms of resistance. In the words of Iphigeneia (Associate Professor, Head of Department): 'these are the conditions of your employment. They might disagree with it but I don’t know... go and work somewhere else [laughs]. It is how it is and if you want to perform here, you do it'. As such, exiting The University was in fact, a form of resistance. As Phillip (Professor) put it the 'perpetual objectors... voted with their feet'. Although academics that had left The University were not interviewed, the voluntary separation process was discussed with long-serving members of this organisation. Chloe (Assistant Professor) argued that while the reform was an important initiative for The University it was applied rather 'ruthlessly': 
...very senior and very committed staff with amazing expertise have felt that there was a need to opt out of the university because of the lack of systems support and an awareness that other people in the same position who were progressing with their $\mathrm{PhD}$ were appointed as assistant professors yet they were not considered and told that they wouldn't be considered.

As such Leto (Professional) noted how 'we lost some extremely good people who were not research active but were very good teachers', a point shared with Roxanne (Assistant Professor).

\section{Resistance as neglect or silence}

While overt resistance was not a realistic option for staff at The University, neglect or silence were more common. This does not signify the interviewees' support of the system, but represents the safer option. One such example was disengaging with the VC's forums, which the academics interviewed did not attend due to lack of time and a general disinterest in big picture items. Hermione (Assistant Professor) claimed the forum was a waste of time: 'in the end, those with power have power. We're not going to change them by standing there shouting at them'. Academics' disengagement with the forum was noted by Alexander (Professional) in a discussion about the lack of attention afforded to professional staff:

In many of the Vice-Chancellor's forums it's the professional staff, not the academics sitting there. We had one yesterday and ninety per cent [of attendees] would be professional staff. So, if I was to be critical I'd say we're not directing the correct messages at the right people.

Recalcitrance also came in the form of a 'lower willingness to do things without clear rewards’ (Dowling-Hetherington, 2016). For example, Penelope (Assistant Professor), in attempting to find some time to do research said no to a project, a response she came to regret 
due to the limited opportunities available as discussed above. According to Roxanne (Assistant Professor), who at the time of the interviews and for a period of approximately a year was Acting Head of Department, ECAs developed 'tunnel vision' in the sense that all their efforts were directed towards publications. Having been at The University for several years, she claimed that before 2007 her colleagues were much keener 'to put their hand up whereas now everyone’s saying “no, I have no time, I'm researching”’. Hermione (Assistant Professor), a disgruntled employee who was actively job searching at the time, exemplified this form of resistance: 'on my list of priorities I have what's necessary and what's not necessary, and basically, I only do what's necessary'.

Finally, one example of resistance in the form of a conscious choice to remain silent was identified, even in situations where the staff member had ideas or suggestions. Daphne (Assistant Professor) who has since left The University explained:

I used to sit with my colleagues in [previous employer] and have raging debates. It wasn't like we didn’t like each other... [but] you do that in academia, it's part of scholarly debate. I didn’t know they didn’t enjoy it here. So, I sit at meetings now and I don’t speak because it's the safest way for me to be, because if I speak, I'm likely to be in trouble. I find that very disheartening.

\section{Discussion}

The metaphor of the game allows us to link the empirical findings to the theoretical concepts, players struggling over the definition of the rules of the game and the distribution of stakes (Hofbauer, Kreissl, Sauer and Striedinger, 2015). To do so, the first task is to identify what is at stake in the field or the valuable forms of capital. The second task is to understand the extent to which people are captured in the game or the extent to which they have 'succumbed to the illusio' (Lupu and Empson, 2015: 1312), and the third to show how the game and its 
stakes have achieved the status of doxa, 'an acceptance that the world is as is' (Dick, 2008: 330).

Viewing academia as a game allows us to acknowledge that part of the game is career progression. Securing a dominant position through acquiring the types of capital that have value in the field is at stake for individuals aspiring to this achievement. In this case, the valuable capital has been determined in the PA criteria, which active players then use to prove their ability and by extension their perceived merit to their assessors. As noted by Bourdieu, illusio is linked with a search for recognition, 'a fascinated pursuit of the approval of others' (Bourdieu, 2000: 166).

Furthermore, the metaphor of the game allows us to acknowledge that the academic players are in fact, in competition with each other for a handful of permanent positions. The struggle for the accumulation of capital, in the form of journal publications, high teaching scores and so on, can therefore be seen as a means to overcome the uncertainty competition causes among the players in the field. The competitive nature of the game is also evident in the case study by the fact that individuals openly challenged management only when an unfavourable evaluation was perceived to be jeopardising their chances for promotion. In that regard, the findings point to a paradox. The same game, which necessitates collective organisation among academics for successful resistance, is the very same game which, by pitting colleagues against each other, makes collective resistance difficult, leaving every person to fend for themselves. While academics complained about the collapse of collegiality they failed to appreciate that their own actions and behaviour accentuated what they simultaneously decried. Thus, this case study shows a 'visceral' (Bourdieu, 2000:102) commitment to the game despite an increased ‘authoritarian control over the lecturer labour process’ (Mather and Seifert, 2014: 96). 
Moreover, the metaphor of the game enables us to recognise symbolic violence, the exercise of power on social agents with their complicity, which manifests in this case study via academics playing this new game, which allows them to pursue career advancement and affirm their status, while effectively misrecognising the intent to enforce and sustain managerialist practices. Thus, resistance, or lack thereof, helps explain how the game became legitimised and reached the status of doxa.

Individuals who either do not want to or who have not been successful in achieving career progression, 'must try individually or collectively, to subvert this logic’ (Dick, 2008: 337). The evidence shows that traditional route to collective resistance - the trade union - was not taken up by staff at The University. Instead, resistance remained on an individual level, which is attributed to the competitive nature of the game academics are engaged in. One way through which academics individually attempted to undermine the dominant logic of the field, was through exiting it. Gabriel (2008: 321) argues that exiting an organisation 'has become one of the key forms of resistance in today's organisations', which he attributes to consumerism becoming the dominant cultural archetype. He argues: 'exit ... represents a take it or leave it attitude that does not seek to confront or challenge social reality, but places the highest value on individuals' freedom to act as they please’ (Gabriel, 2008: 322). The evidence in this case study supports Gabriel's (2008) argument that exit is a resistance strategy adopted by numerous academics. However, this article maintains that exit is an option primarily taken by those who are no longer invested in the game or in Bourdieusian terms, are no longer captured by the illusio.

\section{Conclusion}

By conceptualising academic work as a game, this article makes several contributions. First, it adds to the wider debate about managerialism in HE as well as the implications this has for the 
future of the academy. Second, it can more holistically explain the reasons behind academics' resistance or acquiescence to managerialist imperatives thus filling a gap in the existing literature. Third, the case study indicates that the introduction of performance appraisal as part of a new agenda, challenged the ethos of academic work and the values of collegiality upon which the academy was built. With a much greater emphasis on individual performance measuring grants won, publications published and teaching scores received, the collective community is eroded and one is only as good as the most recent scores. Being a good colleague is not assessed and it is every person for themselves.

While it is not suggested that academics are passive recipients of managerial change, this case study indicates that despite strong ideological objections their resistance is rather limited 'as it acts to ameliorate - rather the overthrow- managerialism' (Anderson, 2008: 267). Most of the interviewees did not see any option but to comply with the new regime to maintain employment in an increasingly insecure labour market as well as progress in their careers. From such a perspective, interviewees' actions represent symbolic violence and thus the case study begs the question: is it inevitable that in choosing compliance, academics become neoliberal subjects, 'enterprising selves, bidding for external research funds and manically producing outputs' (Leathwood and Read, 2013: 1165)? If we are all invested in the game has our complicity left us with exit as the only option for resistance? If not, then who can resist, in terms of levels of seniority, gender or even age and how?

Thus, this work also raises significant questions about resistance in the academy. Given the evidence presented above, this article suggests that unions might not be powerful enough to subvert the managerialist logic. Being mindful of the limitations of consultative committees in challenging managerial prerogative (Barnes and MacMillan, 2014) and despite what on the surface appears to be an elaborate participative system, in practice these appear to operate more as avenues for managers to express voice and for employees to listen rather than 
genuine participation structures (Barry and Wilkinson, 2016). The findings suggest that there is a need for avenues for voice that can challenge the managerial prerogative in academia.

This work is not without limitations. It draws on a single case-study, which limits the generalisation of the findings. However, Yin (2003) pointed out that the logic case study design should follow is replication, which is the logic followed in experiments. Thus, this limitation can be used as avenue for further research in the sense that other scholars could replicate this design and apply it in different contexts. A second limitation of this article is that it draws on a limited number of interviews, an issue which is addressed in the methodology section by highlighting that the consistency of emerging themes across the interviews satisfies concerns regarding saturation. Third, the data is cross-sectional when a longitudinal analysis would have been much more insightful. Though this limitation of the research design is acknowledged, it is argued that the case study sheds light into an interesting juncture in the life of The University. Finally, one could consider the sample of ECAs as a limitation that has skewed the results. However, the sample raises significant questions regarding the future of the academy. Finally, following Bourdieu's (1988) reflexive sociological approach we acknowledge that as voice researchers and academics, we have a vested interest in uncovering deep-seated conflicts and otherwise silenced voices.

Acknowledgements: The authors wish to thank the editor and the three anonymous reviewers for the helpful and constructive comments.

\footnotetext{
${ }^{\mathrm{i}}$ Equivalent to tenure
} 
ii The performance expectations also have an unsatisfactory and a borderline scale defined respectively as: 'does not meet minimum standards' and 'inconsistently meets minimum standards'. These are not broken down into specifics 


\section{References}

Allen-Collinson J (2000) Social science contract researchers in higher education: perceptions of craft knowledge. Work, Employment and Society 14(1): 159-171.

Alvesson M and Spicer A (2016) (Un)conditional surrender? Why do professionals willingly comply with managerialism. Journal of Organizational Change 29(1): 29-45.

Anderson G (2008) Mapping academic resistance in the managerial university. Organization 15(2): 251-270.

Anderson G (2006) Carving out time and space in the managerial univerity. Journal of Organizational Change Management 19(5): 578-592

Archer L (2008) The neoliberal subjects? Young/er academics' constructions of professional identity. Journal of Educational Policy 23(3): 265-285.

Baldry C and Barnes A (2012) The open-plan academy: space, control and the undermining of professional identity. Work, Employment and Society 26(2): 228-245.

Barnes A and MacMillan C (2014). The difficult challenge faced by hybrid employee voice in the Australian university sector. In Gollan PJ, Kaufman B, Taras D and Wilkinson A (eds) Voice and Involvement at Work: Experience with Non-Union Representation. London: Routledge, 101-124.

Barry M and Wilkinson A (2016) Pro-social or pro-management? A critique of the conception of employee voice as a pro-social behaviour within Organizational Behaviour. British Journal of Industrial Relations 54(2): 261-284

Bourdieu P (1977) Outline of a theory of practice. Cambridge: Cambridge University Press. Bourdieu P (1988) Homo academicus. Stanford: Stanford University Press.

Bourdieu P (1991) Language and symbolic power. Cambridge, MA: Harvard University Press.

Bourdieu P (1998) Practical reason. Cambrige: Polity Press.

Bourdieu P (2000) Pascalian Meditations. Stanford, CA: Stanford University Press

Bourdieu P (2005) The social structures of economy. Cambridge: Polity.

Bourdieu P and Wacquant L (1992) An invitation to reflexive sociology. Cambridge: Polity Press.

Brannick T and Coghan D (2007) In defense of being 'native': the case for insider academic research. Organizational Researh Methods 10(1): 59-74

Clarke C, Knights D and Jarvis C (2012) A labour of love? Academics in business schools. Scandinavian Journal of Management 28(1): 5-15

Clegg S (2008) Academic identities under threat? British Educational Research Journal, 34(3): 329-345 
Colley H (2012) Not learning in the workplace: austerity and the shattering of illusio in public service work. Journal of workplace learning 24(5): 317-337

Czarniawska B and Genell K (2002) Gone shopping? Universities on their way to the market. Scandinavian Journal of Management 18(4): 455-474.

Davies B and Petersen EB (2005) Intellectual workers (un)doing neoliberal discourse. International Journal of Critical psychology 13(1): 32-54.

Dick P (2008) Resistance, gender and Bourdieu's notion of field. Management Communication Quarterly 21(3): 327-343

Dowling-Hetherington L (2016) University change in Ireland: understanding the 'what', the 'why' and the 'how'. Educational Management Administration and Leadership 44(2): 263280.

Faulconbridge J and Muzio D (2008) Organizational professionalism in globalizing law firms. Work, Employment and Society 22(1): 7-25

Flyvbjerg B (2006) Five misunderstandings about case-study research. Qualitative Inquiry 12(2): 219-245.

Gabriel Y (2008) Spectacles of Resistance and Resistance of Spectacles. Management Communication Quarterly 21(3): 310-326

Grenfell M (2008) Interest. In Grenfell M (ed) Pierre Bourdieu: Key concepts. Durham: Acumen, 153-170

Hammersley M (1990) Reading ethnographic research:a critical guide. London, New York: Longman

Hofbauer J, Kreissl K, Sauer B and Striedinger A (2015) Of trump cards and game moves: the role of gender equality in power struggles in Universities. In Tatli A, Ozbilgin M and Karatas-Ozkan M (eds) Pierre Bourdieu, Organisation and Management. London: Routledge, 139-161

Hughes J (2005) Bringing emotion to work: emotional intelligence, employee resistance and the reinvention of character. Work, Employment and Society 19(3): 603-625.

Kallio KM, Kallio TJ, Tienari J and Hyvonen T (2016) Ethos at stake: performance management and academic work in universities. Work, Employment and Society 69(3): 685709.

Kamoche K, Kannan S and Siebers LQ (2014) Knowledge-sharing, control, compliance and symbolic violence. Organization Studies 35(7): 989-1012.

Leathwood C and Reid B (2013) Research policy and academic performativity: compliance, contestation and complicity. Studies in Higher Education 38(8): 1162-1174.

Lupu I and Empson L (2015) Illusio and overwork: playing the game in the accounting field. Accounting, Auditing \& Accountability Journal 28(8): 1310 - 1340

Mather K and Seifert R (2014) The close supervision of education lecturers: 'You have been weighed, measured and found wanting'. Work, Employment and Society 28(1): 95-111. 
Mercer J (2007) The challenges of insider research in educational institutions: wielding a double-edged sword and resolving delicate dilemmas. Oxford Review of Education 33(1):117

Parker M (2014) University, Ltd: Changing a business school. Organization 21(2): 281-292.

Ritchie J and Spencer L (2011) Qualitative Data Analysis for Applied Policy Research. In Huberman AM and Miles MB (eds) The Qualitative Researcher's Companion. Thousand Oaks, London and New Delhi: Sage, 305-329

Sousa C, de Nijs WF and Hendriks P (2010) Secrets of the beehive: performance management in university research organisations. Human Relations 63(9): 1439-1460.

Stake RE (1995) The art of case study research. Thousand Oaks, London and New Delhi: Sage

Teelken C (2012) Compliance or pragmatism: how do academics deal with managerialism in higher education? A comparative study in three countries. Studies in Higher Education 37(3): 271-290

Townley B (1997) The institutional logic of performance appraisal. Organization Studies 18(2): 261-285.

Webb J, Schirato T and Danaher G (2002) Understanding Bourdieu. Los Angeles; London; New Delhi; Singapore; Washington DC: Sage

Yin R (2003) Case Study Research: Design and Methods. Thousand Oaks, California: Sage.

Ylijoki OH and Ursin J (2013) The construction of academic identity in the changes of Finnish higher education. Studies in Higher Education 38(8): 1135-1149. 


\section{Author Biographies}

Senia Kalfa is a Lecturer at the Department of Business in the Faculty of Business and Economics at Macquarie University. She holds a PhD from the University of New South Wales and an MSc in Human Resource Management from Aston Business School, Birmingham (UK). Senia's research focuses on the impact of managerialism in academia; employee voice and management practice; and the effect of chronic illness on individuals' work-related identity.

Adrian Wilkinson is Professor and Director of the Centre for Work, Organisation and Wellbeing at Griffith University, Australia. Adrian has authored/co-authored/edited 25 books and over 150 articles in academic journals. Recent books include: The Oxford Handbook of Employment Relations (OUP, 2014); Voice and Involvement at Work: Experience with NonUnion Representation Across Three Continents (Taylor and Francis) and; the Handbook of Research on Employee Voice (Elgar 2014). He is a Fellow and Accredited Examiner of the Chartered Institute of Personnel and Development in the UK and a Fellow of the Australian Human Resource Institute. Adrian was appointed a British Academy of Management Fellow in 2010. He was elected as an Academician (Fellow) of the Academy of Social Sciences in the UK as well as a Fellow of the Academy of Social Sciences in Australia.

Paul J. Gollan is a Senior Professor of Management at the Faculty of Business, University of Wollongong. He is currently Visiting Professor of Management at Kings College London and Honorary Adjunct Professor at MGSM. He holds an MSc (Econ) and PhD from the London School of Economics. Previously Paul was Professor and Director of Australian Institute for Business and Economics at the University of Queensland. He was also Professor of Management and Associate Dean (Research) in the Faculty of Business and Economics at Macquarie University as well as a Visiting Professor in the Department of Management at the 
London School of Economics. Paul has authored, co-authored and co-edited 14 books in the fields of management, human resources and industrial relations including The Oxford Handbook of Participation in Organizations, (2010, Oxford University Press.). Paul is a Chartered Fellow of the Chartered Institute of Personal and Development (UK), and Fellow of the Australian Human Resource Institute. He has also written over 34 book chapters and 52 refereed journal articles. He has published over 250 articles in media outlets such as the Australian Financial Review 


\begin{tabular}{|l|l|l|}
\hline Pseudonyms & Gender & \\
& & \\
\hline Socrates & Male & Profition \\
\hline Daphne & Female & Assistant Professor \\
\hline Thalia & Female & HR Manager \\
\hline Phillip & Male & Professor \\
\hline Roxanne & Female & Assistant Professor \\
\hline Alexander & Male & Office of Deputy VC \\
\hline Medeia & Female & Assistant Professor \\
\hline Kassandra & Female & Librarian \\
\hline Helen & Female & Faculty Manager \\
\hline Leto & Female & Academic Policy \\
\hline Nepheli & Female & HR Professional \\
\hline Persephone & Female & Finance Professional \\
\hline Alkmini & Female & Technical Officer \\
\hline Damon & Male & Librarian \\
\hline Iphigenia & Female & Associate Professor, Head of Department \\
\hline Sofia & Female & Research Office \\
\hline Penelope & Female & Assistant Professor \\
\hline Chloe & Female & Assistant Professor \\
\hline Hermione & Female & Assistant Professor \\
\hline Elektra & Female & Professor, Head of Department \\
\hline Table 1: Particpant & Details & \\
\hline
\end{tabular}

Table 1: Participant Details 